Article

\title{
The Potential of Wetlands in Achieving the Sustainable Development Goals of the 2030 Agenda
}

\author{
Samaneh Seifollahi-Aghmiuni ${ }^{1, *}{ }^{\circledR}$, Minnoka Nockrach $^{2}$ and Zahra Kalantari ${ }^{1}$ (1) \\ 1 Department of Physical Geography and Bolin Center for Climate Research, Stockholm University, \\ SE-106 91 Stockholm, Sweden; zahra.kalantari@natgeo.su.se \\ 2 Department of Physical Geography, Stockholm University, SE-106 91 Stockholm, Sweden; \\ nockrach@gmail.com \\ * Correspondence: samaneh.seifollahi@natgeo.su.se; Tel.: +46-(0)72-923-7558
}

Received: 28 February 2019; Accepted: 20 March 2019; Published: 24 March 2019

\begin{abstract}
Wetlands used as cost-effective nature-based solutions provide environmental and socio-economic benefits to people locally and regionally. With significant loss of wetland areas due to expansion of forest, agriculture, and energy production industries, some countries, including Sweden, have begun providing economic support for environmental objectives for wetland conservation and restoration. Targeting such objectives and setting up relevant plans can decrease the risk of losing valuable wetland-related benefits and help achieve the United Nations Sustainable Development Goals (SDGs). Different ranges of wetland ecosystem services are broadly addressed by the SDGs, however, target-based assessments are required to better understand wetland functionality for sustainable development. This study investigates whether and how wetland ecosystems at local and regional scales can contribute to achieving the SDGs and their targets in Sweden. Scientific literature, policy documents, and international reports on Swedish wetland ecosystems are scrutinized to exemplify the SDGs and their targets, applying a scoring framework based on their interactions. This reveals that, overall, Swedish wetland ecosystems and implemented management plans can positively interact with 10 SDGs and 17 targets at different levels. The analysis also highlights synergies that need to be considered for integrated environmental governance and enhanced policy coherence for Swedish wetland management.
\end{abstract}

Keywords: ecosystem services; nature-based solutions; policy coherence; scoring approach; sustainable development goals; wetland

\section{Introduction}

Wetlands are essential for local and global freshwater-related ecosystems and sustain many terrestrial life forms, significantly contributing to unique biodiversity with their complexity and diversity of species [1,2]. Wetlands as natural sources of methane $\left(\mathrm{CH}_{4}\right)$ [3] can affect carbon sequestration [3], and thus greenhouse gas emissions. They are biologically diverse and productive ecosystems and provide a high number of ecosystem services by providing human well-being and biodiversity benefits $[2,4,5]$, and therefore can be used as nature-based solutions ( $\mathrm{NbS})$, to protect, sustainably manage, and restore degraded natural ecosystems. Moreover, taking into account predicted future changes in hydrological patterns caused by global climate change, wetlands can increase resilience to drought, floods and damage caused by extreme weather scenarios [6,7]. However, increased demand for, and exploitation of, wetland ecosystem services have placed stress on wetlands worldwide [8,9]. Wetlands are often treated as wastelands, which results in pollution, eutrophication, overexploitation of resources, and introduction of alien species into wetland landscapes. 
Wetlands as NbS can help in achieving many of the Sustainable Development Goals (SDGs) set by the United Nations (UN) in its 2030 Agenda, by restoring naturally occurring ecosystems through for example, land and water management [10]. Working with naturally occurring ecosystems instead of the more common restoration projects involving high maintenance man-made strategies and adopting a broader perspective on the SDGs can lead to more sustainable and cost-effective solutions to current global challenges [4,11]. Wetlands of international importance are identified by the Ramsar Convention as unique solutions for conserving biological diversity [12]. They are relevant for the SDGs that relate to quality and supply of water, food and water security, sustainable human settlements, poverty eradication, innovation and development of appropriate infrastructure [13]. However, the potential of wetland services has not yet been integrated into many of the national wetland inventories around the world [6].

The UN's 2030 Agenda for sustainable development is underpinned by 17 SDGs and 169 targets [14] and directs national policy makers to achieve progress across the economic, social and environmental dimensions of sustainable development world-wide. As the process moves towards implementation of solutions, there is a need to address the scope and systemic nature of the 2030 Agenda and the urgency of the challenges facing societies. This requires a wide range of science-based analyses to navigate that complexity and identify the interlinkages between the SDGs and their targets. Such analyses can support more coherent and effective decision making, and facilitate better follow-up and monitoring of progress. To devise coherent policies and strategies for wetland management, it is essential to think systematically about the interactions between the SDGs and their targets, beyond their synergies and trade-offs to develop long-lasting sustainable development plans.

Sweden's system of environmental objectives consists of a generation goal (defined as the measures needed for society to reach the national environmental quality objectives (EQOs) within one generation, i.e., by 2020) [15]. Some government agencies, together with the county administration boards, review and evaluate the progress. The CABs strive to ensure fulfilment of the EQOs in every county by engaging, updating, and coordinating regional agencies and bodies, voluntary organizations, businesses, and other stakeholders. The EQOs focus on the environment, but it is possible that SDGs concerning other areas can be affected by, or affect, achievement of the Swedish EQOs, specifically those for wetlands. Large parts of Sweden's wetlands have been drained and thus lost since the early $19^{\text {th }}$ century. In addition, many of Sweden's remaining wetlands are impacted by drainage and other water operations, forestry, nitrogen deposition, damage from vehicles and by no longer being cut for herbage or grazing. Many types of wetlands will also be impacted negatively by climate change and the establishment of alien species. Damaged wetlands have a reduced capacity to provide important ecosystem services, such as binding and storage of carbon, cleaning water, providing flood protection, and thus reduced contribution to achieving sustainability [16].

This study investigates the interactions between Swedish wetland ecosystem services (and management strategies for these at local and regional scales) and the SDGs and their targets by addressing the following question: How do wetland ecosystem services contribute to achieving multiple SDGs and their targets? All SDGs and targets in the 2030 Agenda are investigated, using published research on Swedish wetlands selected according to their relevance to the SDGs, wetlands, peatlands, greenhouse gases, biodiversity, and NbS. Following target-based assessments, all interactions identified is scored/rated according to wetland ecosystems and to current policies and management strategies. Strategies involved in decision making may not coincide with strategies for implementation $[17,18]$, stressing the importance of looking at the entire policy cycle in order to achieve greater coherence [19]. Visualizing the potential of Swedish wetland ecosystems to move towards multiple SDGs and their targets can provide a better understanding of their different synergies and interactions, and support better policy making considerations for Swedish wetland management. 


\section{Study Region}

Sweden has one of the world's highest densities of wetlands, occupying an area of 9-10 million hectares predominantly in the north of the country, which represents one-fifth of the country's land area (Figure 1). Sweden also has the highest variation in wetland types within the European Union (EU) and, after Russia, it has the largest wetland area in Europe [20]. By 2018, Sweden designated 68 sites, covering a total surface area of 665,474 hectares, as internationally important Ramsar sites [21]. Large areas of different types of wetlands were lost in the early 19th century, due to expansion of forest industries and agricultures. Additionally, vast areas (primarily in the south of the country) were drained for extraction of peat for energy production, resulting in the loss of one-quarter of Swedish wetlands [22]. In this study, Swedish wetland ecosystems and the services they provide are used to illustrate $\mathrm{NbS}$ for achieving multiple SDGs and their targets simultaneously.

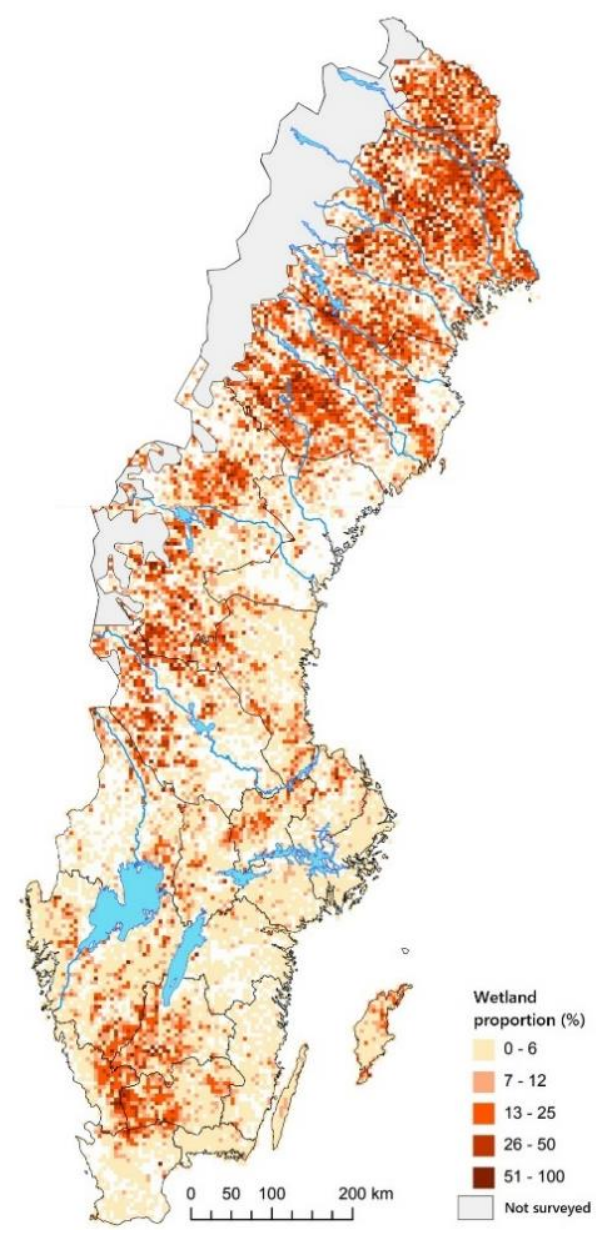

Figure 1. Wetland distribution in Sweden [20]. Reproduced from publicly available national report for wetland inventory in Sweden entitled "The Swedish Wetland Survey"; published by Swedish Environmental Protection Agency (Naturvårdsverket), 2014.

\section{Materials and Methods}

The scientific community has emphasized the need for a systems approach to sustainable development [23-25], but policy-makers face the challenge of implementing the SDGs. To address this challenge, a scoring framework (Figure 2) has been established to stimulate more science-policy dialogue on the importance of SDGs interactions, to provide a starting point for policy-makers and other stakeholders in setting their priorities and implementation strategies, and to engage the policy community in further knowledge developments in this field [26]. It can help decision-makers and policy-makers recognize the potential of target-based assessments by identifying negative or positive 
interactions among SDGs and their targets [27,28]. The key dimensions in the scoring framework are time, geography, governance, technology, and directionality, which describe the interactions and define the context in which they occur. Most interaction scores depend on these dimensions, so introducing the right policies and technologies could shift the score to a more positive value [26].

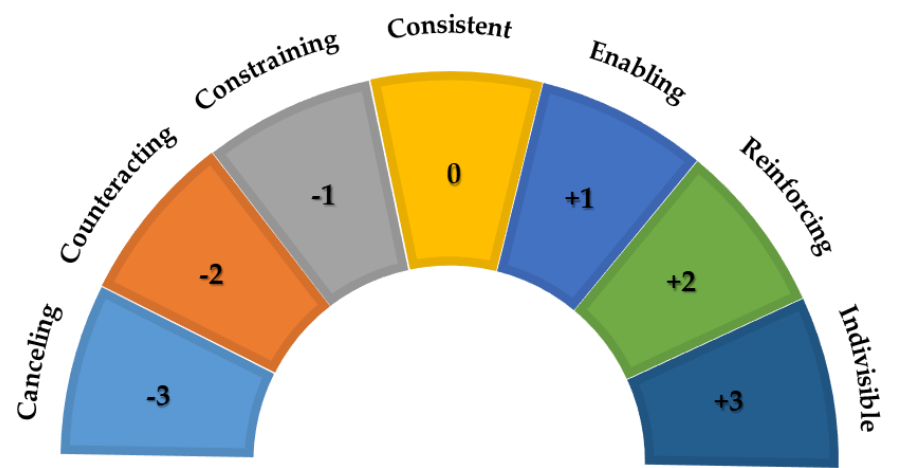

Canceling: Progress in one goal/target makes it impossible to reach another goal/target and possibly leads to a deteriorating state of the second.

Counteracting: The pursuit of one goal/target counteracts another goal/target.

Constraining: The pursuit of one goal/target sets a condition or a constraint on the achievement of another.

Consistent: A neutral relationship where one goal/target does not significantly interact with another or where interactions are deemed to be neither positive nor negative.

Enabling: The pursuit of one goal/target enables the achievement of another goal/target.

Reinforcing: One goal/target directly creates conditions that lead to the achievement of another goal/target.

Indivisible: One goal/target is inextricably linked to the achievement of another goal/target.

Figure 2. Scoring framework for interactions between the United Nations Sustainable Development Goals (SDGs) and targets [26].

Within the scoring framework, positive interactions are assigned a score of +1 (enabling), +2 (reinforcing), or +3 (indivisible), while interactions characterized by trade-offs are assigned a score of -1 (constraining), -2 (counteracting), or -3 (cancelling) (Figure 2). Thus, the magnitude of the score, in whatever direction, provides an indication of how influential a given SDG or target is on another. Not all interactions and trade-offs between SDGs and targets fall neatly into one of the seven score classes, but the scale does provide a sufficiently wide range to classify most relationships [26]. As can be seen in Figure 2, the highest positive score $(+3)$ is associated with joint and paired goals/targets, while the highest negative score $(-3)$ is related to goals/targets that cannot be achieved together.

In the present analysis, a literature study is conducted using a data availability and data/methodological approach as regards local-regional wetland functions (municipal data, policy documents), international reports on wetland services (e.g., Ramsar), and literature concerning the SDGs and wetland ecosystems. Municipality data and policy documents were collected from Swedish government agencies such as the Swedish Environmental Protection Agency. For instance, an extensive survey of 35,000 Swedish wetland sites, collected over a 25-year timeline that was assembled in 2014 in a report [20] was used for understanding the different characters of wetlands and ecosystem services in Sweden. In addition, international reports on wetland status from organizations such as Ramsar and the Fifth Assessment Report of the Intergovernmental Panel on Climate Change (IPCC) on freshwater resources [29] were used for indications and predictions on current and coming changes for wetlands on a global scale. The scoring framework shown in Figure 2 is applied in this study by assigning positive scores to different SDGs and their targets in accordance with their possible positive interactions (enabling, reinforcing, indivisible) with Swedish wetland ecosystem services and their management strategies. Negative interactions (cancelling, counteracting, constraining) and consistent interactions are not investigated in this study due to lack of available scientific data. 


\section{Results and Discussion}

A total of 10 SDGs and 17 targets that positively interact with wetland ecosystem services in Sweden are identified by applying the scoring framework (Table 1). In this table, a score of +1 , associated with enabling interactions, is assigned to the SDGs and targets for which the conditions required for their achievement can potentially be created by conservation and management plans for Swedish wetland ecosystems and services. For instance, preventing marine pollution of all kinds (SDG 14-target 14.1) is supported by the ability of wetlands to prevent hazardous run-off from the terrestrial floodplain entering the ocean (Table 1). A score of +2 , associated with reinforcing interactions, is given to SDGs and targets that can be directly achieved based on particular Swedish wetland services. As an example, reducing the number of deaths and illnesses from hazardous contaminations (SDG 3-target 3.9) benefits from the wetland service of storing mercury in permafrost areas and diminishing the spread and accumulation of mercury in food chains (Table 1). Moreover, a score of +3 , indicating indivisible interactions, is given to SDGs and targets that are inextricably linked to Swedish wetland ecosystem services and thus have a strong and positive interaction with their management and protection. For example, access to safe and affordable drinking water (SDG 6-target 6.3) requires access to local fresh water resources, which can effectively be recharged by wetland services that allow water to be filtered and re-deposited in local deep-water aquifers (Table 1).

Ecosystem services are categorized in a number of different ways in the literature, including by: (i) functional groupings, such as regulation, carrier, habitat, production, and information services; (ii) organizational groupings, such as services that are associated with certain species that regulate some exogenous input, or that are related to the organization of biotic entities; and (iii) descriptive groupings, such as renewable resource goods, non-renewable resource goods, physical structure services, biotic services, biogeochemical services, information services, and social and cultural services [30]. Considering functional groupings within the Millennium Ecosystem Assessment, all ecosystem services can be classified within categories of provisioning, regulating, cultural, and supporting services [30]. For operational purposes, in the following sections we focus on Swedish wetland ecosystem services in the regulating category and discuss those relevant to the SDGs and targets listed in Table 1.

Table 1. Positive interactions between the United Nations Sustainable Development Goals (SDGs) and their targets and Swedish wetland ecosystems. Description of SDGs and targets are taken from UN's 2030 Agenda [28].

\begin{tabular}{|c|c|c|c|c|c|}
\hline Score & Category & \multicolumn{4}{|c|}{ Relevant SDGs and Targets } \\
\hline \multirow{4}{*}{$\begin{array}{c}+1 \\
\text { Enabling }\end{array}$} & & 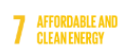 & 11 sistramberines & 14 Belowwater & \\
\hline & SDG & $\left.z^{\prime \prime \prime}\right)^{\prime}=$ & 囲A & & \\
\hline & & 乐 & 禩住画 & & \\
\hline & Target & 7.1 & 11.B & $14.1 ; 14.3$ & \\
\hline \multirow{2}{*}{ 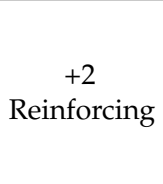 } & SDG & 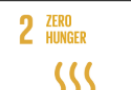 & 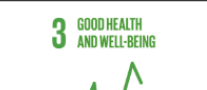 & 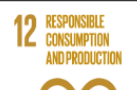 & \\
\hline & Target & 2.4 & 3.9 & 12.2 & \\
\hline \multirow{3}{*}{$\begin{array}{c}+3 \\
\text { Indivisible }\end{array}$} & & $1 \stackrel{\text { No }}{\text { POVERTY }}$ & 6 GiEANWATER & 13 ciumati & 15 IFE \\
\hline & SDG & 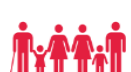 & & & \\
\hline & Target & 1.5 & $6.1 ; 6.3 ; 6.4 ; 6.6$ & $13.1 ; 13.2$ & $15.1 ; 15.5 ; 15 . \mathrm{A}$ \\
\hline
\end{tabular}

SDG 1. End poverty in all its forms everywhere.

Target 1.5. By 2030, build the resilience of the poor and those in vulnerable situations and reduce their exposure and vulnerability to climate-related extreme events and other economic, social and environmental shocks and disasters. 
Table 1. Cont.

SDG 2. End hunger, achieve food security and improve nutrition and promote sustainable agriculture.

Target 2.4. By 2030, ensure sustainable food production systems and implement resilient agricultural practices that increase productivity and production, that help maintain ecosystems, that strengthen capacity for adaptation to climate change, extreme weather, drought, flooding and other disasters and that progressively improve land and soil quality.

SDG 3. Ensure healthy lives and promote well-being for all at all ages.

Target 3.9. By 2030, substantially reduce the number of deaths and illnesses from hazardous chemicals and air, water and soil pollution and contamination.

SDG 6. Ensure access to water and sanitation for all.

Target 6.1. By 2030, achieve universal and equitable access to safe and affordable drinking water for all. Target 6.3. By 2030, improve water quality by reducing pollution, eliminating dumping and minimizing release of hazardous chemicals and materials, halving the proportion of untreated wastewater and substantially increasing recycling and safe reuse globally.

Target 6.4. By 2030, substantially increase water-use efficiency across all sectors and ensure sustainable withdrawals and supply of freshwater to address water scarcity and substantially reduce the number of people suffering from water scarcity.

Target 6.6. By 2020, protect and restore water-related ecosystems, including mountains, forests, wetlands, rivers, aquifers and lakes.

SDG 7. Ensure access to affordable, reliable, sustainable and modern energy for all.

Target 7.1. By 2030, ensure universal access to affordable, reliable and modern energy services.

SDG 11. Make cities inclusive, safe, resilient and sustainable.

Target 11.B. By 2020, substantially increase the number of cities and human settlements adopting and implementing integrated policies and plans towards inclusion, resource efficiency, mitigation and adaptation to climate change, resilience to disasters, and develop and implement, in line with the Sendai Framework for Disaster Risk Reduction 2015-2030, holistic disaster risk management at all levels.

SDG 12. Ensure sustainable consumption and production patterns.

Target 12.2. By 2030, achieve the sustainable management and efficient use of natural resources.

SDG 13. Take urgent action to combat climate change and its impacts.

Target 13.1. Strengthen resilience and adaptive capacity to climate-related hazards and natural disasters in all countries.

Target 13.2. Integrate climate change measures into national policies, strategies and planning.

SDG 14. Conserve and sustainably use the oceans, seas and marine resources.

Target 14.1. By 2025, prevent and significantly reduce marine pollution of all kinds, in particular from land-based activities, including marine debris and nutrient pollution.

Target 14.3. Minimize and address the impacts of ocean acidification, including through enhanced scientific cooperation at all levels.

SDG 15. Sustainably manage forests, combat desertification, halt and reverse land degradation, halt biodiversity loss.

Target 15.1. By 2020, ensure the conservation, restoration and sustainable use of terrestrial and inland freshwater ecosystems and their services, in particular forests, wetlands, mountains and drylands, in line with obligations under international agreements.

Target 15.5. Take urgent and significant action to reduce the degradation of natural habitats, halt the loss of biodiversity and, by 2020, protect and prevent the extinction of threatened species.

Target 15.A. Mobilize and significantly increase financial resources from all sources to conserve and sustainably use biodiversity and ecosystems.

\subsection{Water Regulation}

From a hydrological perspective, changes in climate, drought, and other precipitation patterns may have severe consequences for water availability [8]. In Northern Europe, there has been an unexpected increase in the frequency and magnitude of floods and droughts, with more intensive 
rainfall usually in confined local areas. Less precipitation during winter, together with a longer snow melt period, is predicted to reduce peak spring floods [8]. This reduction can lead to substantial seasonal reductions in water supply systems and increase the risk of forest fires in spring and summer in Sweden [31]. The ability of wetlands to support the water cycle maintains groundwater level and provides soil moisture regulation (SDG 2-target $2.4(+2)$ and SDG 6-target $6.4(+3)$ ) [32,33]. Water quality protection [34] through safeguarding the ability of wetlands to maintain a steady water supply of clean drinking water for humans and nature all around the planet [6] can improve safe and affordable drinking water availability for all (SDG 12-target $12.2(+2)$, SDG 1-target $1.5(+3)$, SDG 6-target 6.1 (+3), SDG 13-target $13.1(+3)$, and SDG 15-target $15.5(+3))$ and reduce the need to import water. Wetland hydraulics can help to maintain a steady recharge of freshwater to deep drainage aquifers [30]. Increased irrigation and droughts place added stress on water reservoirs [20]. This stress can be alleviated by the capability of wetlands for retaining runoff water from precipitation and melting snow, letting it percolate through the ground and re-filling the water reservoirs. This provides good water quantity and quality, by preventing valuable water from being transported away from the location across terrestrial floodplains (SDG 2-target $2.4(+2)$, SDG 12-target $12.2(+2)$, and SDG 6-targets $6.1(+3)$ and $6.4(+3))$.

Coastal wetlands provide shoreline stabilization [35] by preventing coastal erosion through retaining sediment and accumulating new sediment that is transported from terrestrial flood systems (SDG 15-target 15.1 (+3)). Protecting coastal wetland ecosystems strengthens their resilience to the impact of storm-driven waves, thus providing storm protection in coastal zones (SDG 11-target 11.B (+1), SDG 12-target 12.2 (+2), SDG 1-target 1.5 (+3), SDG 13-target $13.1(+3)$, and SDG 15-target 15.5 (+3)) [36]. For example, Swedish coastal wetlands adjacent to the Baltic Sea can act as nutrient sinks, reducing upstream nutrient emissions to marine waters [35] if the water body passes through a wetland area (SDG 14-target $14.1(+1)$ and SDG 3-target $3.9(+2)$ ). Natural flood regulation supplies sediment transportation within the moving bodies of water, providing the conditions for agricultural activities by depositing nutrients and fresh water for irrigation (SDG 2-target 2.4 (+2)) [37,38]. By incorporating wetlands into the agricultural landscape, hazardous runoff can be avoided (SDG 14-target 14.1 $(+1)$, SDG 6-target $6.3(+3)$, and SDG 15-target $15.5(+3))$. Practicing sustainable agriculture in the local community diminishes the risk of food and water shortages which are leading to costs for economically exposed groups (SDG 2-target $2.4(+2)$, SDG 1-target $1.5(+3)$, SDG 6-targets $6.1(+3)$ and $6.4(+3)$, and SDG 13-target $13.1(+3)$ ). Flood regulation enables production of carbon-free energy (hydropower) for use in housing and various industries, providing the foundation for further development in human societies (SDG 1-target $1.5(+3)$ and SDG 7-target $7.1(+1)$ ) without releasing hazardous gases into the atmosphere (SDG 14-targets $14.1(+1)$ and $14.3(+1)$ ). However, it is important to assess the environment surrounding hydropower plants, and weigh the benefits and losses for biodiversity [39]. Hydropower production adds pressure on water resources and would therefore benefit from the re-filling capabilities of wetlands [40].

Restoring and protecting natural wetlands helps to maintain one of the Earth's most complex and unique ecosystems, which provides a high biodiversity of life forms (SDG 3-target 3.9 (+2), SDG 6-target 6.6 (+3), and SDG 15-targets $15.1(+3)$ and $15.5(+3))$. Many red-listed flora and fauna are directly connected to these habitats. Wetlands can reduce the exposure to climate-related effects and associated economic, social, and environmental shocks and disasters (SDG 1-target 1.5 (+3)). Available scientific data indicate that wetlands reduce the effects on communities in vulnerable situations [13] by increasing their resilience to drought and flooding in the environment and by providing multiple ecosystem services that help to buffer the impact of climate change (SDG target $1.5(+3)$ ).

Swedish wetland ecosystem services contribute positively to achievement of all SDGs identified in Table 1, as well as most of their targets (Figure 3). As shown in Figure 3, all identified SDGs in Table 1 are connected to wetland ecosystem services regarding water regulation in their landscapes. In addition, among all identified targets, our target-based assessments have indicated that only target 13.2 (SDG 13) and target 15.A (SDG 15) are not relevant. As water-related landscape features, Swedish 
wetlands interact particularly with the SDG 6 (Ensure access to water and sanitation for all) and SDG 14 (Conserve and sustainably use the oceans, seas and marine resources), since all of their identified targets can be met by natural wetland ecosystem services and their water regulation aspects.

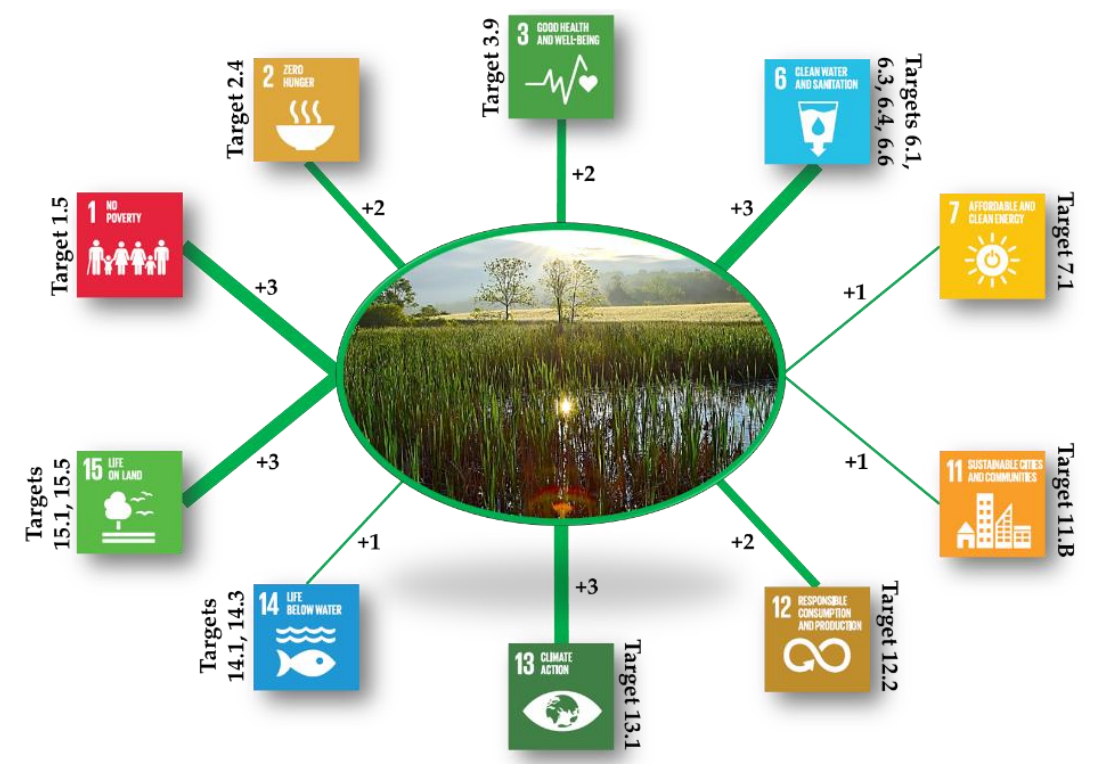

Figure 3. Positive water regulation interactions identified between United Nations Sustainable Development Goals (SDGs) and Swedish wetland ecosystem services. Photo: http://www. kimointernational.org/feature/swedish-municipalities-harness-ecosystem-services/.

\subsection{Climate Regulation}

Peatlands are natural climate regulators, since they slow down heating of the atmosphere (SDG 13-target $13.1(+3)$ ). Protecting and restoring peatlands reduces the amount of $\mathrm{CO}_{2}$ available in the atmosphere, as well as the amount of energy that can be absorbed for climate events (SDG 12-target $12.2(+2)$ and SDG 13-target $13.1(+3))$. This decreases the intensification of extreme weather events (SDG 6-target $6.4(+3)$ ) that leave vulnerable ecosystems and populations (e.g., infants and the elderly) exposed to symptoms of overheating and water stress (SDG 3-target 3.9 (+2), SDG 1-target 1.5 (+3), and SDG 15-target $15.5(+3))$. The low primary production and slow decomposition rates in Swedish wetlands allow them to accumulate the same amount of carbon as regions with higher decomposition rates generated by higher precipitation and a longer growing season, resulting in carbon accumulation rates equivalent to those observed for U.S. soils [41].

According to the Intergovernmental Panel on Climate Change (IPCC), rewetting drained peatlands could lead to a substantial reduction in annual greenhouse gas emissions to the atmosphere (SDG 11-target 11.B (+1)) [42,43]. This would prevent further insulation of the planet by lessening the greenhouse effect [44]. This in turn would reduce the amount of energy available for climate-related hazards and natural disasters (SDG 3-target $3.9(+2))$ and less extreme and intensive climate effects (SDG 1-target $1.5(+3)$, SDG 6-target $6.4(+3)$, SDG 13-target $13.1(+3)$, and SDG 15-target $15.5(+3)$ ), by e.g., reducing the acidification of oceans (SDG 14-target $14.3(+1)$ ) [45].

Among the 10 SDGs and 17 targets with positive interactions with Swedish wetland ecosystem services identified in Table 1, achievement of eight SDGs and eight targets can be supported through protecting these landscape features (Figure 4). While each SDG is given a specific score in Table 1, there is just one target for each that is relevant to wetland ecosystem services regarding climate regulation. 


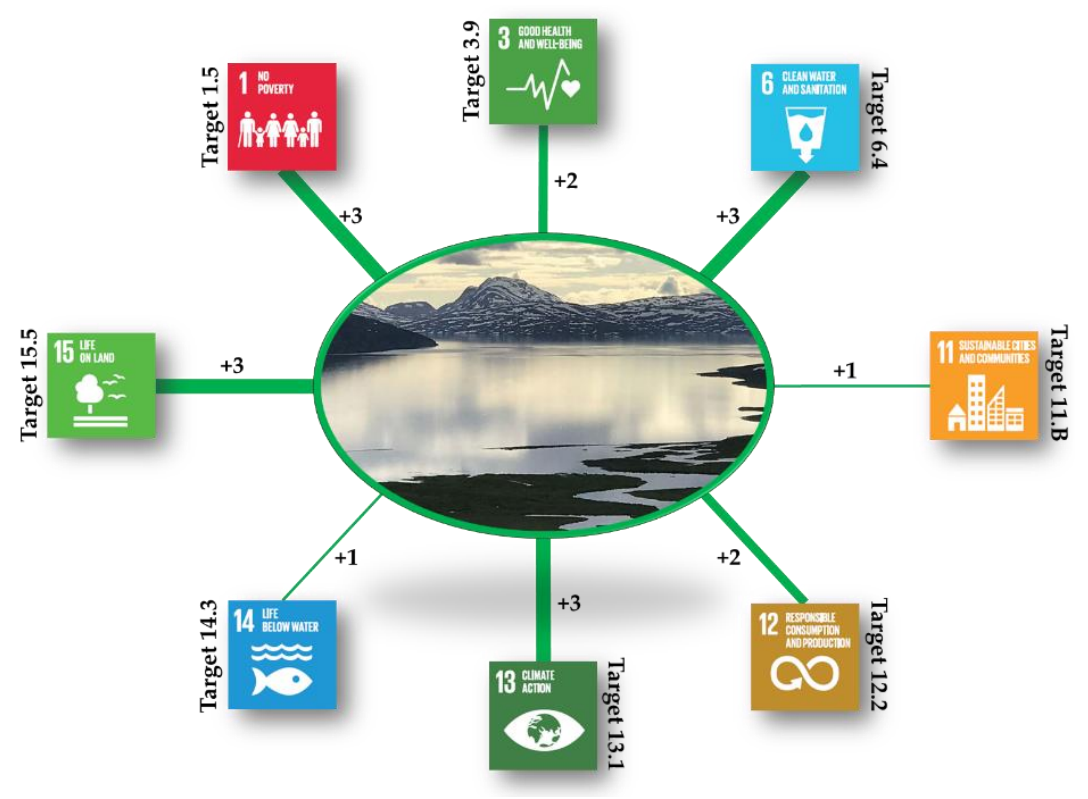

Figure 4. Positive climate regulation interactions identified between United Nations Sustainable Development Goals (SDGs) and Swedish wetland ecosystem services. Photo: https:/ /www.sei.org/ projects-and-tools / projects/resilience-and-management-of-arctic-wetlands /.

\subsection{Water Purification}

Studies of high-latitude peatlands with permafrost have shown that, apart from storing carbon, they have the capacity for storing lead and mercury in an atrophic methylated state by binding them to organic material in the active layer [44]. Mercury contamination can derive from local and regional areas, but consists primarily of atmospheric mercury, and thus high-latitude peatlands provide a global storage basin for mercury (SDG 14-target $14.1(+1)$ and SDG 6-6.3 (+3)) [46]. However, thawing due to climate change can convert these vast permafrost areas from carbon/mercury sinks into carbon/mercury sources [47]. When released, the mercury in the ecosystem will bio-accumulate in trophic food chains [48], devastating the population of top predators and thus threatening the biodiversity of animals, often causing severe economic and social shocks (SDG 1-target $1.5(+3)$ ). This is one of the crucial reasons for stopping further temperature increases in high-latitude areas (SDG 3-target $3.9(+2)$, and SDG 13-targets $13.1(+3)$ and $13.2(+3)$ ).

Man-made wetlands for treatment of sewage water achieve a positive reduction in biological oxygen demand, chemical oxygen demand, suspended solids and fecal coliforms (SDG 14-target 14.1 (+1), SDG 3-target 3.9 (+2), SDG 6-target 6.3 (+3), and SDG 15-target $15.1(+3))$. However, their potential for reducing the concentrations of ammonia-nitrogen and phosphorus deriving from sewage water is declining and these landscape features are no longer as efficient in this regard [49]. Water shortages for vulnerable populations can result in use of contaminated water, leading to serious health concerns. The ability of wetlands to slow down flowing water allows deposition of suspended particles and solutions for sedimentation. This allows plants and microbial organisms to reduce the amount of harmful substances subjected to further transportation (SDG 6-target $6.3(+3)$ ) [44], lessening the impact on vulnerable ecosystems and populations (SDG 11-target 11.B (+1), SDG 14-target 14.1 (+1), SDG 3-target $3.9(+2)$, SDG 1-target $1.5(+3)$, SDG 13-target $13.1(+3)$, and SDG 15-target $15.5(+3))$. The area of man-made wetlands is increasing, but their quality is not as good as that of natural wetlands $[6,50]$. Natural wetlands are also cheaper to maintain and restore than man-made wetlands [51] when used for combating climate-related extreme events (SDG 1-target 1.5 (+3)). As a result of the Swedish national strategy for investment in wetlands, the indivisible target of 15.A (SDG 15) is being actively implemented [52]. This investment reduces the degradation of natural habitats, 
strengthening biodiversity and deep-water drainage systems (SDG 15-targets $15.1(+3)$ and $15.5(+3)$ ), through guidelines for policies and management (SDG 11-target 11.B (+1), and SDG 12-target $12.2(+2)$ ).

Figure 5 shows eight SDGs and 10 targets relevant to Swedish wetland ecosystem services regarding water purification in the landscape. SDGs 13 and 15 have a higher correlation, since two targets for each are related to these types of wetland ecosystem services.

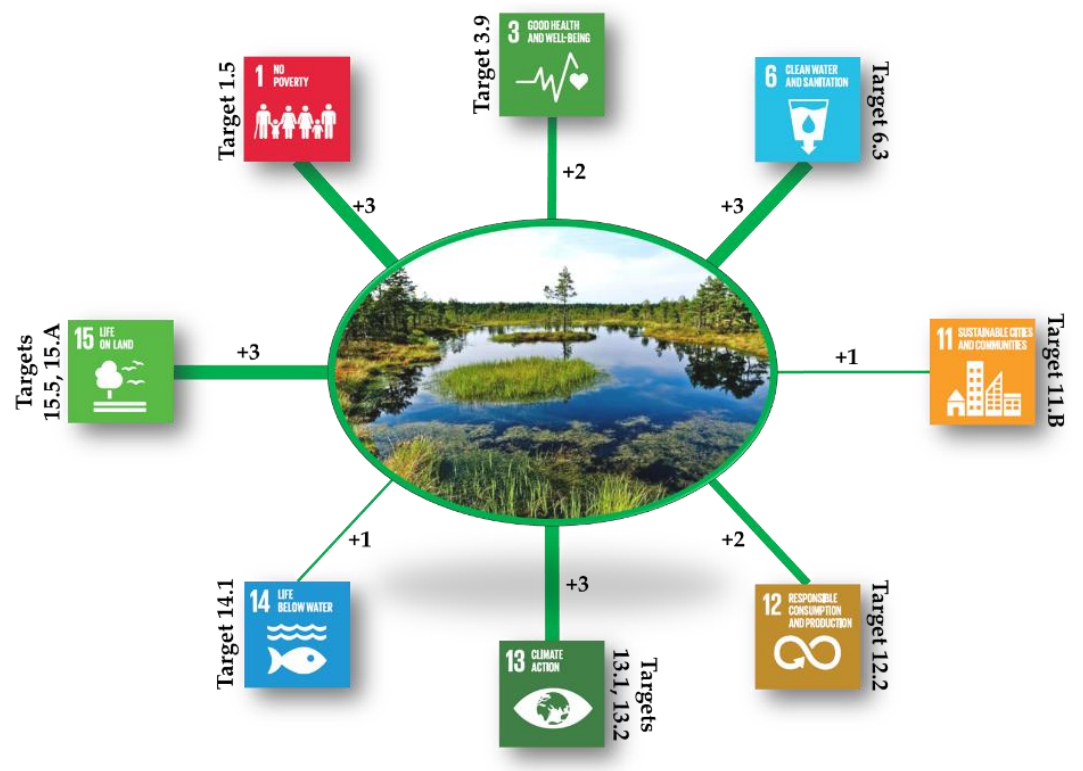

Figure 5. Positive water purification interactions identified between United Nations Sustainable Development Goals (SDGs) and Swedish wetland ecosystem services. Photo by Dmitri Korobtsov.

\subsection{Challenges of Achieving Multiple SDGs Regarding Wetland Management}

General functions and ecosystem services of wetlands as natural landscape features can be similar in different places, while there are of course differences which need to be considered in looking at their contribution to achieving the SDGs and their targets. Climate conditions, landscape characteristics, diverse ecosystems, human-induced interventions, and protection and restoration plans for wetlands vary among different regions in the world. This highlights possibly the need for investigating the interactions between SDGs and their targets and wetland ecosystem services at regional scale considering wetland characteristics and challenges they are facing with. In addition, different countries make different policies and recommendations as wetland restoration and protection plans depending on their national and regional priorities. These plans would affect such interactions, and regional target-based assessments would be required to explore wetlands' contributions to moving towards multiple SDGs and their targets in different regions.

Policy and scientific studies have shown that it is difficult to manage multiple SDGs simultaneously, as there are many factors that need to be addressed. To achieve the fullest potential of the SDGs, understanding the complexity of the individual goals and targets and their interactions with other goals and targets is very important. All SDGs interact with one another-by design they are an integrated set of global priorities and objectives that are fundamentally interdependent. Understanding the range of positive and negative interactions among SDGs is key to unlocking their full potential at any scale, and to ensuring that progress made in some areas is not achieved at the expense of progress in others. The nature, strengths, and potential impacts of these interactions are largely context-specific and depend on the policy options and strategies chosen to pursue them. For many if not all SDGs, having in place effective governance systems, institutions, partnerships, and intellectual and financial resources is key to an effective, efficient and coherent approach to implementation [15]. However, the priority given to different SDGs and targets differs between countries depending on their national 
objectives, causing specific goals to be prioritized to favor certain needs over others, regardless of former analyses [26].

To reach the full potential of SDGs, it is important to change the ways in which policies and management plans are made. The focus should be on policies and plans for solving different challenges that apply to and affect many actors that share the same area of interest. For example, integrating climate change measures for strategies when planning wetland management leads to achievement of SDG 13-target 13.2 (identified as an indivisible target in this study). Actors should to observe the defined tasks for each SDG and work on them as a network, combining the different goals around a single purpose and thereby creating coherent policies. Various integrated environmental governance concepts for increased collaboration are dependent on identifying the actors involved in a specific issue that enhanced collaboration would benefit, increasing the chances of solving the issue [19] and even enabling the possibility to achieve multiple SDGs. Establishing common principles for all actors would counteract the risk of imbalance in decision making and implementation, which can affect weaker actors [19].

Making adjustments when handling trade-offs can lead to conflicting interest between sectors, inhibiting coherency among actors and deflecting opposing interests by allowing environmental protection to be prioritized over other objectives for achieving multiple SDGs [46]. This can be overcome by giving priority to long-term sustainability of the environment and simultaneously balancing the economic and social gains in a short-term perspective [53]. Stimulating a bottom-up approach to meta-governance that is based on the principles of inclusiveness, transparency, and accountability could make it easier to set priorities for different levels of governance (national, regional and local) [54].

\section{Conclusions}

Demand for clean drinking water is steadily increasing and global water resources are under high social and economic pressure. With the ongoing climate change caused by human activities, a clear understanding of how increasing global mean temperature affects the hydrological cycle at both global and local scales is crucial. By taking advantage of existing natural ecosystems, such as wetlands, it is possible to combat the trend of a warming planet. Multiple services provided by wetlands can act as essential NbS for achieving different SDGs and particular targets, for instance, by reducing greenhouse gases and environmental toxins, maintaining a stable groundwater level, and even cooling the planet. This study highlights the possibilities within Swedish wetland ecosystems to help achieve SDGs and their targets. Application of a scoring framework to classify SDGs and their targets in accordance with their interactions with wetland ecosystem services in Sweden resulted in identification of 10 SDGs and 17 targets with enabling, reinforcing and indivisible interactions. Many of these SDGs and targets are manageable/achievable by the same wetland services. For instance, wetland interactions with the water cycle from both quantity and quality aspects are in line with SDGs 1 , $2,6,12$, and 13 and their specific targets. Thus, efforts aiming to manage and restore Swedish wetlands can lead to achievement of the SDGs and other national environmental quality objectives. However, when developing wetland management plans, there is a need to replace the business-as-usual approach with an intelligible and inclusive approach, highlighting the possibilities wetland ecosystems provide to coherently address SDGs and their specific targets. Such an approach would give a broader view on achieving multiple SDGs by decreasing the risk of losing valuable resources for environmental and socio-economic benefits derived from Swedish wetlands. It is crucial that policy-makers in various domains avoid undermining each other's efforts to establish a network and instead strive for policy coherence, continuous development, and implementation of comprehensive strategies to achieve all relevant SDGs and targets.

Author Contributions: All authors have contributed substantially to this work, as specified below: Manuscript writing and editing: S.S.-A. Main analysis and writing of some parts: M.N. Research idea and contribution to writing and editing: Z.K. 
Funding: This research received no external funding.

Conflicts of Interest: The authors declare no conflict of interest.

\section{References}

1. Gibbs, J.P. Wetland loss and biodiversity conservation. Conserv. Biol. 2000, 14, 314-317. [CrossRef]

2. Thorslund, J.; Jarsjö, J.; Jaramillo, F.; Jawitz, J.W.; Manzoni, S.; Basu, N.B.; Chalov, S.R.; Cohen, M.J.; Creed, I.F.; Goldenberg, R.; et al. Wetlands as large-scale nature-based solutions: Status and challenges for research, engineering and management. Ecol. Eng. 2017, 108, 489-497. [CrossRef]

3. Watson, R.T.; Noble, I.R.; Bolin, B.; Ravindranath, N.H.; Verardo, D.J.; Dokken, D.J. (Eds.) Special Report of the IPCC on Land Use, Land-Use Change, and Forestry; Cambridge University Press: Cambridge, UK, 2000.

4. Kalantari, Z.; Ferreira, C.S.S.; Deal, B.; Destouni, G. Nature-based solutions for meeting environmental and socio-economic challenges in land management and development. Land Degrad. Dev. 2019, 1-4. [CrossRef]

5. Mitsch, W.J.; Bernal, B.; Nahlik, A.M.; Mander, Ü.; Zhang, L.; Anderson, C.J.; Jørgensen, S.E.; Brix, H. Wetlands carbon, and climate change. Landsc. Ecol. 2013, 28, 583-597. [CrossRef]

6. The Ramsar Convention. The 4th Strategic Plan 2016-2024, The Convention on Wetlands of International Importance especially as waterfowl habitat-The Ramsar Convention. In Proceedings of the 12th Meeting of the Conference of the Parties at Punta Del Este, Uruguay, South America, 1-9 June 2015.

7. Kalantari, Z.; Ferreira, C.S.S.; Keesstra, S.; Destouni, G. Nature-based solutions for flood-drought risk mitigation in vulnerable urbanizing parts of East-Africa. Curr. Opin. Environ. Sci. Health 2018, 5, 73-78. [CrossRef]

8. Jiménez Cisneros, B.E.; Oki, T.; Arnell, N.W.; Benito, G.; Cogley, J.G.; Döll, P.; Jiang, T.; Mwakalila, S.S. Freshwater resources. In Climate Change 2014: Impacts, Adaptation, and Vulnerability. Part A: Global and Sectoral Aspects, 1st ed.; Contribution of Working Group II to the Fifth Assessment Report of the Intergovernmental Panel on Climate Change; Field, C.B., Barros, V.R., Dokken, D.J., Mach, K.J., Mastrandrea, M.D., Bilir, T.E., Chatterjee, M., Ebi, K.L., Estrada, Y.O., Genova, R.C., et al., Eds.; Cambridge University Press: Cambridge, UK; New York, NY, USA, 2014; pp. 229-269.

9. Goldenberg, R.; Kalantari, Z.; Cvetkovic, V.; Mörtberg, U.; Deal, B.; Destouni, G. Distinction, quantification and mapping of potential and realized supply-demand of flow-dependent ecosystem services. Sci. Total Environ. 2017, 593-594, 599-609. [CrossRef] [PubMed]

10. The Ramsar Convention on Wetlands. Scaling up Wetland Conservation, Wise Use and Restoration to Achieve the Sustainable Development Goals. 2018; pp. 1-13. Available online: https:/ /www.ramsar.org/ sites/default/files/documents/library/wetlands_sdgs_e.pdf (accessed on 23 March 2019).

11. Keesstra, S.D.; Nunes, J.; Novara, A.; Finger, D.; Avelar, D.; Kalantari, Z.; Cerdà, A. The superior effect of nature based solutions in land management for enhancing ecosystem services. Sci. Total Environ. 2018, 610-611, 997-1009. [CrossRef]

12. The Ramsar Convention. The List of Wetlands of International Importance. 2019, pp. 1-54. Available online: http:/ / archive.ramsar.org/cda/en/ramsar-documents-list/main/ramsar/1-31-218_4000_0__(accessed on 23 March 2019).

13. Sarabhai, K.V. ESD and Sustainable Development Goals. J. Educ. Sustain. Dev. 2014, 8, 1-2. [CrossRef]

14. United Nations. Transforming Our World: The 2030 Agenda for Sustainable Development. Resolution Adopted by the General Assembly on 25 September 2015. Available online: http:/ / www.un.org/ga/search/ view_doc.asp?symbol=A/RES/70/1\&Lang=E (accessed on 12 March 2019).

15. Sweden Environmental Protection Agency. Sweden's Environmental Objectives-An Introduction. 2012; pp. 9-24. Available online: http:/ / www.swedishepa.se/Documents/publikationer6400/978-91-620-8620-6. pdf?pid=6759 (accessed on 23 March 2019).

16. Swedish Environmental Protection Agency (Naturvårdsverket). Available online: http: / /www.swedishepa.se/Environmental-objectives-and-cooperation/Swedens-environmental-objectives / The-national-environmental-objectives/Thriving-Wetlands/ (accessed on 12 March 2019).

17. Persson, Å. Different perspectives on EPI. In Environmental Policy Integration in Practice: Shaping Institutions for Learning, 1st ed.; Nilsson, M., Ed.; Taylor and Francis Group: London, UK, 2007; pp. 25-48. 
18. van Asselt, H. Legal and political approaches in interplay management: Dealing with the fragmentation of global climate governance. In Managing Institutional Complexity: Regime Interplay and Global Environmental Change; Oberthür, S., Stokke, O.S., Eds.; The MIP Press Scholarship Online: Cambridge, MA, USA, 2011; pp. 59-85.

19. Weitz, N.; Strambo, C.; Kemp-Benedict, E.; Nilsson, M. Closing the governance gaps in the water-energy-food nexus: Insights from integrative governance. Glob. Environ. Chang. 2017, 45, 165-173. [CrossRef]

20. Gunnarsson, U.; Löfroth, M. The Swedish Wetland Survey; Swedish Environmental Protection Agency (Naturvårdsverket): Frösön, Sweden, 2014; p. 22.

21. The Ramsar Sites Information Service. Available online: https://www.ramsar.org/wetland/sweden (accessed on 15 February 2019).

22. Swedish Environmental Protection Agency (Naturvårdsverket). Available online: https://www. naturvardsverket.se/Sa-mar-miljon/Vatten/Vatmark/ (accessed on 15 February 2019).

23. Johansson, T.B.; Nakicenovic, N.; Patwardhan, A.; Gomez-Echeverri, L. Global Energy Assessment-Toward a Sustainable Future; Cambridge University Press and the International Institute for Applied Systems Analysis: Laxenburg, Austria, 2012.

24. van Vuuren, D.; Kok, M.; van der Esch, S.; Jeuken, M.; Lucas, P.; Prins, A.G.; Alkemade, R.; van den Berg, M.; Biermann, F.; van der Grijp, N.; et al. Roads from Rio+20 Pathways to Achieve Global Sustainability Goals by 2050; PBL Netherlands Environmental Assessment Agency: The Hague, The Netherlands, 2012.

25. Stafford Smith, M.; Gaffney, O.; Brito, L.; Ostrom, E.; Seitzinger, S. Interconnected risks and solutions for a planet under pressure-Overview and introduction. Curr. Opin. Envn. Sustain. 2012, 4, 3-6. [CrossRef]

26. Nilsson, M.; Griggs, D.J.; McCollum, D.; Stevance, A. (Eds.) A Guide to SDG Interactions: From Science to Implementation; International Council for Science (ICSU): Paris, France, 2017.

27. Nilsson, M.; Dzebo, A.; Savvidou, G.; Axelsson, K. A bridging framework for studying transition pathways-From systems models to local action in the Swedish heating domain. Technol. Forecast. Soc. Chang. 2018, in press. [CrossRef]

28. United Nations (UN). Available online: https://www.un.org/sustainabledevelopment/sustainabledevelopment-goals (accessed on 15 February 2019).

29. Intergovernmental Panel on Climate Change (IPCC). Fifth Synthesis Report: Climate Change; Intergovernmental Panel on Climate Change (IPCC): Geneva, Switzerland, 2014; pp. 1-151.

30. Millennium Ecosystem Assessment (MEA). Ecosystems and Human Well-being: Wetlands and Water Synthesis. 2005, pp. 30-38. Available online: http://hdl.handle.net/20.500.11822/8735 (accessed on 12 March 2019).

31. Kovats, R.S.; Valentini, R.; Bouwer, L.M.; Georgopoulou, E.; Jacob, D.; Martin, E.; Rounsevell, M.; Soussana, J.-F. Europe. In Climate Change 2014: Impacts, Adaptation, and Vulnerability. Part B: Regional Aspects, 1st ed.; Contribution of Working Group II to the Fifth Assessment Report of the Intergovernmental Panel on Climate Change; Barros, V.R., Field, C.B., Dokken, D.J., Mastrandrea, M.D., Mach, K.J., Bilir, T.E., Chatterjee, M., Ebi, K.L., Estrada, Y.O., Genova, R.C., et al., Eds.; Cambridge University Press: Cambridge, UK; New York, NY, USA, 2014; pp. 1267-1326.

32. Hefting, M.; Clément, J.C.; Dowrick, D.; Cosandey, A.C.; Bernal, S.; Cimpian, C.; Tatur, A.; Burt, T.P.; Pinay, G. Water table elevation controls on soil nitrogen cycling in riparian wetlands along a European climatic gradient. Biogeochemistry 2004, 67, 113-134. [CrossRef]

33. Xiong, S.; Johansson, M.E.; Hughes, F.M.R.; Hayes, A.; Richards, K.S.; Nilsson, C. Interactive effects of soil moisture, vegetation canopy, plant litter and seed addition on plant diversity in a wetland community. J. Ecol. 2003, 91, 976-986. [CrossRef]

34. Verhoeven, J.T.A.; Arheimer, B.; Yin, C.; Hefting, M.M. Regional and global concerns over wetlands and water quality. Trends Ecol. Evolut. 2006, 21, 96-103. [CrossRef] [PubMed]

35. The Ramsar Convention. Coastal Management: Wetland Issues in Integrated Coastal Zone Management, 3rd ed.; 2010; pp. 1-52. Available online: https:/ / www.ramsar.org/sites/default/files/documents/pdf/lib/hbk412.pdf (accessed on 23 March 2019).

36. Gren, I.M. Resilience value of constructed coastal wetlands for combating eutrophication. Ocean Coast. Manag. 2010, 53, 358-365. [CrossRef] 
37. Russi, D.; ten Brink, P.; Farmer, A.; Badura, T.; Coates, D.; Förster, J.; Kumar, R.; Davidson, N. The Economics of Ecosystems and Biodiversity (TEEB) for Water and Wetlands; IEEP: London, UK; Brussels, Belgium; Ramsar Secretariat: Gland, Switzerland, 2013.

38. de Groot, R.S.; Wilson, M.A.; Boumans, R.M.J. A typology for the classification, description and valuation of ecosystem functions goods and services. Ecol. Econ. 2002, 41, 393-408. [CrossRef]

39. Acreman, M.; Holden, J. How wetlands affect floods. Wetlands 2013, 33, 773-786. [CrossRef]

40. Renöfält, B.M.; Jansson, R.; Nilsson, C. Effects of hydropower generation and opportunities for environmental flow management in Swedish Riverine ecosystems. Freshw. Biol. 2010, 55, 49-67. [CrossRef]

41. Merriman, L.S.; Moore, T.L.C.; Wang, J.W.; Osmond, D.L.; Al-Rubaei, A.M.; Smolek, A.P.; Blecken, G.T.; Viklander, M.; Hunt, W.F. Evaluation of factors affecting soil carbon sequestration services of stormwater wet retention ponds in varying climate zones. Sci. Total Environ. 2017, 583, 133-141. [CrossRef]

42. Hiraishi, T.; Krug, T.; Tanabe, K.; Srivastava, N.; Jamsranjav, B.; Fukuda, M.; Troxler, T. (Eds.) Methodological guidance on lands with wet and drained soils, and constructed wetlands for wastewater treatment. In 2013 Supplement to the 2006 IPCC Guidelines for National Greenhouse Gas Inventories: Wetlands; IPCC: Geneva, Switzerland, 2014.

43. Barthelmes, A.; Couwenberg, J.; Risager, M.; Tegetmeyer, C.; Joosten, H. Peatlands and Climate in a Ramsar Context; Nordic Council of Ministers: Copenhagen, Denmark, 2015.

44. Bindler, R. Estimating the natural background atmospheric deposition rate of Mercury utilizing Ombrotrophic bogs in southern Sweden. Environ. Sci. Technol. 2003, 37, 40-46. [CrossRef]

45. National Oceanic and Atmospheric Administration (NOAA). What Is Ocean Acidification? Available online: https:/ / www.pmel.noaa.gov/co2/story/What+is+Ocean+Acidification\%3F (accessed on 15 February 2019).

46. Lafferty, W.M.; Hovden, E. Environmental policy integration: Towards an analytical framework. Environ. Politics 2003, 12, 1-22. [CrossRef]

47. Rydberg, J.; Klaminder, J.; Rosén, P.; Bindler, R. Climate driven release of carbon and mercury from permafrost mires increases mercury loading to sub-Arctic lakes. Sci. Total Environ. 2010, 408, 4778-4783. [CrossRef]

48. Borgå, K.; Fisk, A.T.; Hoekstra, P.E.; Muir, D.C.G. Biological and chemical factors of importance in the bioaccumulation and trophic transfer of persistent organochlorine contaminants in Arctic marine food webs. Environ. Toxicol. Chem. 2004, 23, 2367-2385. [CrossRef] [PubMed]

49. Song, Z.; Zheng, Z.; Li, J.; Sun, X.; Han, X.; Wang, W.; Xu, M. Seasonal and annual performance of a full-scale constructed wetland system for sewage treatment in China. Ecol. Eng. 2006, 26, 272-282. [CrossRef]

50. Leadley, P.W.; Krug, C.B.; Alkemade, R.; Pereira, H.M.; Sumaila, U.R.; Walpole, M.; Marques, A.; Newbold, T.; Teh, L.S.L.; van Kolck, J.; et al. Progress towards the Aichi Biodiversity Targets: An Assessment of Biodiversity Trends, Policy Scenarios and Key Actions; Technical Series; Secretariat of the Convention on Biological Diversity (CBD): Montreal, QC, Canada, 2014; Volume 78, 500p.

51. Arkema, K.K.; Guannel, G.; Verutes, G.; Wood, S.A.; Guerry, A.; Ruckelshaus, M.; Kareiva, P.; Lacayo, M.; Silver, J.M. Coastal habitats shield people and property from sea-level rise and storms. Nat. Clim. Chang. 2013, 3, 913-918. [CrossRef]

52. Swedish Environmental Protection Agency. National Strategy for Thriving Wetlands; Swedish Environmental Protection Agency: Frösön, Sweden, 2005; 32p.

53. Jordan, A.; Lenschow, A. Innovation in Environmental Policy? Integrating the Environment for Sustainability, 1st ed.; Edward Elgar: Cheltenham, UK, 2008.

54. Kooiman, J.; Jentoft, S. Meta-Governance: Values, norms and principles, and the making of hard choices. Public Adm. 2009, 87, 818-836. [CrossRef]

(C) 2019 by the authors. Licensee MDPI, Basel, Switzerland. This article is an open access article distributed under the terms and conditions of the Creative Commons Attribution (CC BY) license (http:/ / creativecommons.org/licenses/by/4.0/). 